\title{
"I was Anti-Everything": Cartoonist Jackie Ormes and the Comics as a Site of Progressive Black Journalism
}

\section{H. Zahra Caldwell}

In 1953, cartoonist Jackie "Zelda" Ormes was featured in the One Tenth of a Nation Newsreel series. She was shown in her studio meticulously drawing her popular comics. This short film was put out by All-American Newsreel, a company that produced some of the only Black newsreels in the twentieth century. They would be shown nationwide at the start of feature films. The One Tenth series featured fourteen prominent African Americans and was an attempt to recognize African American contributions during the 1950s. ${ }^{1}$ By this time, Ormes's comic strips reached millions weekly and she had created one of the first Black, massmarketed dolls, modeled after fictional Patty Jo from her widely circulated Patty Jo ' $n$ ' Ginger strip. Ormes's characters would become so popular that by 1948 , when asked what he might take with him to a desert island, writer Langston Hughes declared, "I would miss . . Jackie Ormes's cute drawings."2 Ormes's inclusion in the film, as well as Hughes's reference, signaled the status she had earned in the Black press and Black popular culture.

When this film was produced Ormes was approaching the zenith of her twenty-year career as a cartoonist in Black newspapers. This made her the longest running, most syndicated Black woman cartoonist, a record still unchallenged in the modern day. Ormes's comics are not simply vehicles for easy laughs; they exist as powerful sites of Black feminist radical clapbacks and pointed societal interrogations. The erasure and marginalization of Black women's artistic, intellectual, and activist labor within histories of the twentieth century will come as no surprise to the reader. Thankfully, these contributions are being steadily unearthed. Scholars such as Mia Bey, Farrah J. Griffin, Martha S. Jones, and 
Barbara D. Savage in their collection Toward an Intellectual History of Black Women and Brittany C. Cooper in her work Beyond Respectability: The Intellectual Thought of Race Women, Ayesha K. Hardison's Writing Through Jane Crow: Race and Gender Politics in African American Literature, among many others, have provided a critical overview of this work by African American women. ${ }^{3}$ Yet we must continue to expand our definitions of both intellectual and activist labor. Black comics, and in Ormes's case, Black women cartoonists occupy a marginalized space in art and activism. Her comics work to upend this marginalization. Her strips are an example of Black women's astute evaluations of the world around them and the interior and exterior challenges mounted to survive them. Her comics provide a valuable unvarnished critique of American life and inequity at midcentury using the voices and bodies of Black female characters.

Decades after her strips ran, Ormes exclaimed to an interviewer, "Me, I was always fighting battles, I was antiwar-I was anti-everything-that's-smelly!"' Due to the lack of a formal or informal Ormes archive, her personal politics are hard to discern in full. What is clear, however, is that she was involved in groups characterized as radical in different capacities, and the worldview she articulated in the few interviews she granted could also be considered radical for the time. However, her comics speak in a clear radical voice and her fight was on display within the pages of the Black press, in a most overlooked place - the funny pages.

I hope to add to the important work on Ormes begun by other scholars. Researcher Nancy Goldstein provides the most comprehensive text on Ormes. Her groundbreaking book, Jackie Ormes: The First African American Woman Cartoonist, gives an overview of her prodigious creative production and her larger life. The widest collection of her comics is collected here, as well as the sole interviews with her then-living relatives. ${ }^{5}$ Literary scholar Edward Brunner discusses the exceptionalism of Ormes's Black female characters in his article, “'Shuh! Ain't Nothin' To It': The Dynamics of Success in Jackie Ormes's 'Torchy Brown." American Studies scholar Deborah Elizabeth Whaley dedicates a chapter to Ormes in Black Women in Sequence: Re-inking Comics, Graphic Novels, and Anime, the only book devoted to Black women's representation in comics to date. The chapter's focus is on Ormes as a producer of what Whaley terms "Black cultural front comics." Looking across her body of work, Whaley identifies Ormes's work as having broad and important political impact. She also rightly places Ormes as a founding artist in a pantheon of Black female cartoonists.

I am adding to this burgeoning discussion by considering the way in which Ormes used her strips as an extension of progressive Black journalism and contemporaneous movements. As a space that was under-scrutinized, the Black comics allowed her to do political work that could not have been done as easily in other artistic or journalistic formats. My article is a brief examination of Ormes's use of her strip to those ends and as a location from which to report, witness, and critique national and international events. First, I turn to the comic's context and significance within the larger Black press, glancing at Ormes's early work 
and inimitable use of the comic as a politicized Black female space; ultimately, I explore her alignment with progressive Black journalism within the Cold War and Civil Rights eras using Patty Jo 'n' Ginger (1945-1956) as a lens.

There were many voices in the Black press, reflecting the diversity of the communities it represented. This included a spectrum from radical to conservative. The Black press, like other branches of the press, incorporated a range of reporting. However, national Black weeklies such as the Pittsburgh Courier had to include wildly varying views under a single banner in order to encompass the collective thinking of Black America. White Americans had many more specialized media venues through which to speak their multiplicities. Even when a Black weekly sought middle ground or tried to eschew radicalism, many of the exigent issues impacting their readers were considered radical in the mainstream. Historian Fred Carroll points out that the "outsized influence on black political life" caused some Black newspaper publishers to include heavy coverage of "radical political views that were frequently at odds with their personal commitment to the national political system and its capitalist economy." "Progressive and radical journalism often willfully confronted structural oppressions such as racism, classism, and sexism. This is especially pertinent during the eras in which Ormes published, which included the Popular and Cultural Fronts as well as the civil rights and early second-wave women's movements. She embraced and aided these movements by placing her work in a more radical position than that of her publishers, and, sometimes, that of her fellow cartoonists and journalists.

\section{The Black Press, Jackie Ormes, and the Politics of Cartooning}

In a segregated America, Black newspapers were a significant part of Black life. Their impact and reach cannot be overstated. The Chicago Defender alone had a circulation of over 150,000, with two-thirds of copies sold outside of Chicago. By the late 1940s Black newspapers had "developed networks of bureaus, zoned editions, and national editions." "The Pittsburgh Courier claimed to have a million readers at the height of its popularity. This may have been inflated, however, their readership was the largest, topping at least $300,000 .{ }^{10}$ It is very likely that readership of these newspapers was more expansive than could be accurately recorded. Many of the papers were shared amongst several readers. Black newspapers had a mission distinct from that of white newspapers, which was to "serve, speak and fight for the black minority," and nearly every inch of a Black newspaper was used to that end. ${ }^{11}$ The comic pages were included in this milieu. At large white mainstream newspapers, even if an artist was inclined to make political commentary, there were many steps of production between themselves and the finalized strip. These papers either paid for syndicated comic strips, or hired a full staff of comic artists who had separate individuals write the narrative, draw the strip, create the dialogue, and finalize the product. Much of the time, several people were involved in the creation of a single strip. Ormes 
and other Black comic strip creators drafted their own narratives, drew their own images, and inserted their own text. ${ }^{12}$ Individualized messaging on the part of the artists allowed for a greater connection to the tenor, triumphs, and struggles of their readership. This is not to say that every strip in the Black press had political or social overtones. However, the omnipresence of problems associated with inequity plaguing their communities meant that they could never be avoided in any part of the paper for long. In Ormes's strips, these issues were a fundamental part of her narratives and her comics' politics.

During her career, Ormes would create four comic strips centered on African American women: Torchy Brown in "Dixie in Harlem" (1937-1938), Candy (1945), Patty Jo 'n' Ginger (1945-1956), and Torchy in Heartbeats (1950-1954). As a high school student in the late 1920s Ormes began working as a cub reporter for the nationally distributed Black newspaper, the Pittsburgh Courier. She was given minor assignments initially, but would cover harder news periodically throughout her career. Drawing was her true passion, and she maneuvered her way to the comics, retaining the eye of a reporter. In 1937, Ormes published her first installment of Dixie. It followed the adventures of a young Black woman who migrated from Mississippi to Harlem. During the nearly twelve-month run of Torchy, the main character participated in activities rare for most Black women, including resisting segregation laws by sitting in the "whites only" train car, traveling across the country, flying on an airplane, and working as a showgirl in exclusive New York nightclubs. Ormes instills a Black feminist sensibility within Torchy and her other Black female protagonists, without exception. They are independent and self-empowered, and each centers the experiences of Black women and their larger communities. Simultaneously, their success or failure is not dependent on men or their proximity to masculinity. Here, in addition to an independent Black feminist sensibility and the commentary on issues such as segregation and migration, Ormes's illustrations symbolize the significance of the Black press in providing images of Blackness that were not tied to the limiting white imagination.

The paper initially published Torchy Brown in "Dixie in Harlem" alongside Sunny Boy Sam by Wilbert Holloway and, later, Society Sue and Family by Sam Milai. Sunny Boy Sam, one of the longest running Black comics, revolved around a male character who was a comedic hustler of sorts and often played into Black stereotypes. For example, he was flashy, mischievous, and spoke in dialect. Society Sue included a woman as a main character, but she was not imbued with the social awareness of Ormes's characters. A renowned cartoonist, Milai would later publish cartoons with a much more political bent. In her early publication as a cartoonist, Ormes described many of the strips that her work appeared alongside as lacking in political substance. She explained, "Now there was a lot of news in the Courier about segregation and such, but these things never made it into the comics. They didn't deal with it at all." ${ }^{\prime 3}$ This comment suggests that Ormes believed the comics should have more directly engaged the glaring concerns of the day. The level of political engagement shifted over time, and it depended 
on who the Courier published in that section. Ormes, along with comic artists such as Oliver Harrington, should be credited with helping to craft the comics as an extension of the political discussions found throughout the Courier and other Black newspapers.

Together with the comic relief in their drawings, Ormes and Harrington delivered easily accessible commentary and progressive opinion pieces for readers. Yale-educated Harrington was a multi-talented artist, reporter, and writer. Before World War II he had published comics and articles for a number of African American papers, including the People's Voice, a radical weekly, and Harlem's mainstream Amsterdam News. After a break from the Courier, he returned in 1943 as a war correspondent and cartoonist. ${ }^{14} \mathrm{He}$ created what was perhaps the most popular strip in Black comics at the time, Dark Laughter, with its unassuming silent protagonist - a middle-aged Black man named Bootsie. Ormes's Patty Jo ' $n$ ' Ginger ran stacked or side by side with Harrington's in the late 1940s and 1950s. More than likely this was a publisher's layout decision as they were both single-pane comics that were contained in one scene and fit easily together for production and publication. This pairing was fortuitous. Her strips raised many of the same social and political questions and critiques as Harrington's.

\section{Candy and Black Feminist Image Activism}

Before publishing Patty Jo ' $n$ ' Ginger Ormes published Candy in The Chicago Defender in 1945. She took a hiatus from the Courier prompted by her move to Chicago. Candy ran only from March to July of that year. The critiques that Ormes spoke through Candy aligned with those found in progressive Black journalism during the war. Despite its short run, its representation of African American women was nearly unrivaled within the comic pages. This was a crucial dimension of Ormes's progressive Black journalism and her activism. Candy is also the character in which one can see Ormes's growing social commentary, which would later be cemented in the characters of Patty Jo and the reincarnated Torchy. Candy centered African American women and, specifically, an African American woman domestic, giving her voice and reconfiguring her image. This centering of Black female characters was almost exclusively found in the works of Black women. ${ }^{15}$ Appearing on the editorial page, mirroring Black opinions of the day and drawn by a Black woman cartoonist, the fictional Candy commented on the state of a country at war. Topics included wartime shortages, a developing Black market for rationed products, so called patriotic activities, and the complications of wartime Black womanhood. In one edition of the strip, Candy, wearing her full maid's uniform, turns to the viewer and says, "I'd better answer this GI mail for Mrs. Goldrocks so SHE'LL have something to brag about at her club meeting." 16 In another, Candy, who Ormes draws looking down at a party from a higher landing, laments, "This job's good for me . . . the more I see of her friends, the more I appreciate my own." ${ }^{17}$ Candy posited Black Americans as possessing a deeper, more profound understanding of equality, freedom, and 
democracy and called out white hypocrisy. Candy's opinions resonated with those expressed by other Black women in the press as well as those in the broader community. In 1946, novelist Ann Petry published The Street which rendered a stark and intimate portrait of a Black woman domestic and the many injustices she faced due to her class, race, and gender. ${ }^{18}$ Communist leader and activist Claudia Jones also pointed to the multilayered exploitation and oppression of Black women workers in her pivotal 1949 essay, "An End to the Neglect of the Problems of the Negro Woman!" She aptly described these women as, "the most oppressed strata of society." 19 Her examination of their labor stretched back to slavery and included World War II.

During the war, Black women served in a variety of capacities including in factory production, as nurses, in the military, as agricultural workers, and, akin to Candy, as domestics. ${ }^{20}$ While African American women routinely served as domestics in the North and South many families who were apt to hire white women turned to Black women during the labor vacuum created by WWII. In 1944 Black women made up sixty percent of all private household workers, up thirteen percent from 1940 figures. ${ }^{21}$ Candy was an important representation of the experience of these Black domestics. Regrettably, Candy's heavy emphasis on wartime issues may have caused its demise. Germany surrendered to the Allied powers in May of 1945, and Candy ended in July of that year.

With Candy and her other strips, Ormes incorporated Black feminist images as she shared portraits of Black life and African American women that were not routinely found in mainstream representations or elsewhere in the Black press. The constructions of Black womanhood she rendered functioned as activism and political commentary in their own right. In the pages of national white newspapers, Black women were nearly nonexistent. The comic pages were no exception. When they did materialize, the appearances of African American women in the national white comic pages were degrading. The comic strip was, and remains, a bastion of white male Americana. Women who appeared in its panes were white, drawn by men, and reflected the white male gaze. This can be seen in Blondie, the most popular strip of the time that featured a woman lead. She reflected a thin one-dimensional construction based on white male desire. The Blondie character had begun her career in comics as a dizzy gold digger with the body of a pinup and was later toned down to a sexy yet wise housewife who was the picture of domestic success. ${ }^{22}$ She was the epitome of virtuous white womanhood, with her sexy blonde appeal and humble domestic focus. African American women had a different role within the white male imagination. Many were sexualized yet were often servants or maids. In either iteration, they were stripped of respectability, agency, intelligence, and independence. The representations and images found in film and print media were troubling not only in their wholesale inaccuracy, but also in how they perpetually placed Black women in bygone eras and denied them membership in the modern world. ${ }^{23}$ The comics of Jackie Ormes profoundly challenged this representation. They resisted both 
deleterious image constructions and sociopolitical repression adding another front of resistance to Black journalism.

\section{Patty Jo 'n' Ginger and Cold War Civil Rights}

Ormes's longest running strip, Patty Jo ' $n$ ' Ginger, likewise confronted these images and repressions. Running from 1945 to 1956, it was her hallmark strip and brought her the most notoriety. It ran in all the editions of the Pittsburgh Courier, to which she had returned. Ormes's ability, in 1945, to begin a comic strip that would run fifty-two weeks a year for over a decade was both remarkable and unprecedented. Comic historian Trina Robbins wrote of the period, "It goes without saying that all those white-shirted men working for Disney were white, white-shirted men. If, after the war, action-oriented comics became a male-only domain, all nationally syndicated comics were, and had been, a whiteonly domain." 24 Ormes broke through the all-white, all-male precincts and left a lasting legacy with her strips. She utilized this hard-earned space as one of progressive, sometimes radical, comic-based journalism.

In the same way that Candy reflected the World War II moment, Patty Jo ' $n$ ' Ginger was very much representative of the turbulent postwar era. The strip's frequent political messaging was anchored by three pillars, the first being the lasting influence of the Popular and Cultural Fronts of the 30s and 40s. The second was the rising Civil Rights Movement, and, third, the Cold War and its resulting anticommunism. The main character in the strip is Patty Jo, a little girl with big opinions. Ormes was able to speak to major issues of the day through her character's innocent musings. Patty Jo's ever-silent teenage sister, drawn in a style akin to pinup-worthy Candy, accompanies her. Both sisters are beautifully drawn, adorned in the latest fashions, and Patty Jo freely shares her opinions about the world around her. Through the one-pane strip, she comments on everything from racial injustice to the unequal treatment of women to national and international politics. Her reflections are always quite innocuous, but have a bite. Patty $J_{o}$ ' $n$ ' Ginger, like other parts of the Black newspaper, spoke to both the conditions of the Black community as well as to its aspirations. Although Patty Jo and Ginger are drawn in a way that prominently displays an aspirational middle-class lifestyle, with all the accoutrements that typically came with it such as home ownership, access to quality education, and evidence of disposable income, the comic also continuously points to the conditions of the Black community as a whole and the national issues that faced Black America at midcentury.

In a particularly pointed 1950 strip, Patty Jo stands in a room within a home that is suffering badly from the impacts of poverty and neglect. Ormes depicts blight by drawing the shoddy conditions: leaky ceilings, broken windows, cracked and peeling walls, and falling rafters. Patty Jo announces facetiously to the three poorly attired kids and their mother, who occupy the wretched space, "Now you folks can REALLY stop worryin' .. . Uncle Sam's blowing our national wad on an H-bomb for your protection . . . course that don't spell HOUSING, but you 
gotta admit, it ain't HAY either!"25 (Figure 1) Here Ormes alludes to the hypocrisy of a government that poured money into the development of the hydrogen bomb and the arms race with its rival superpower, Russia, while it neglected domestic issues like severe urban blight, particularly in African American communities.

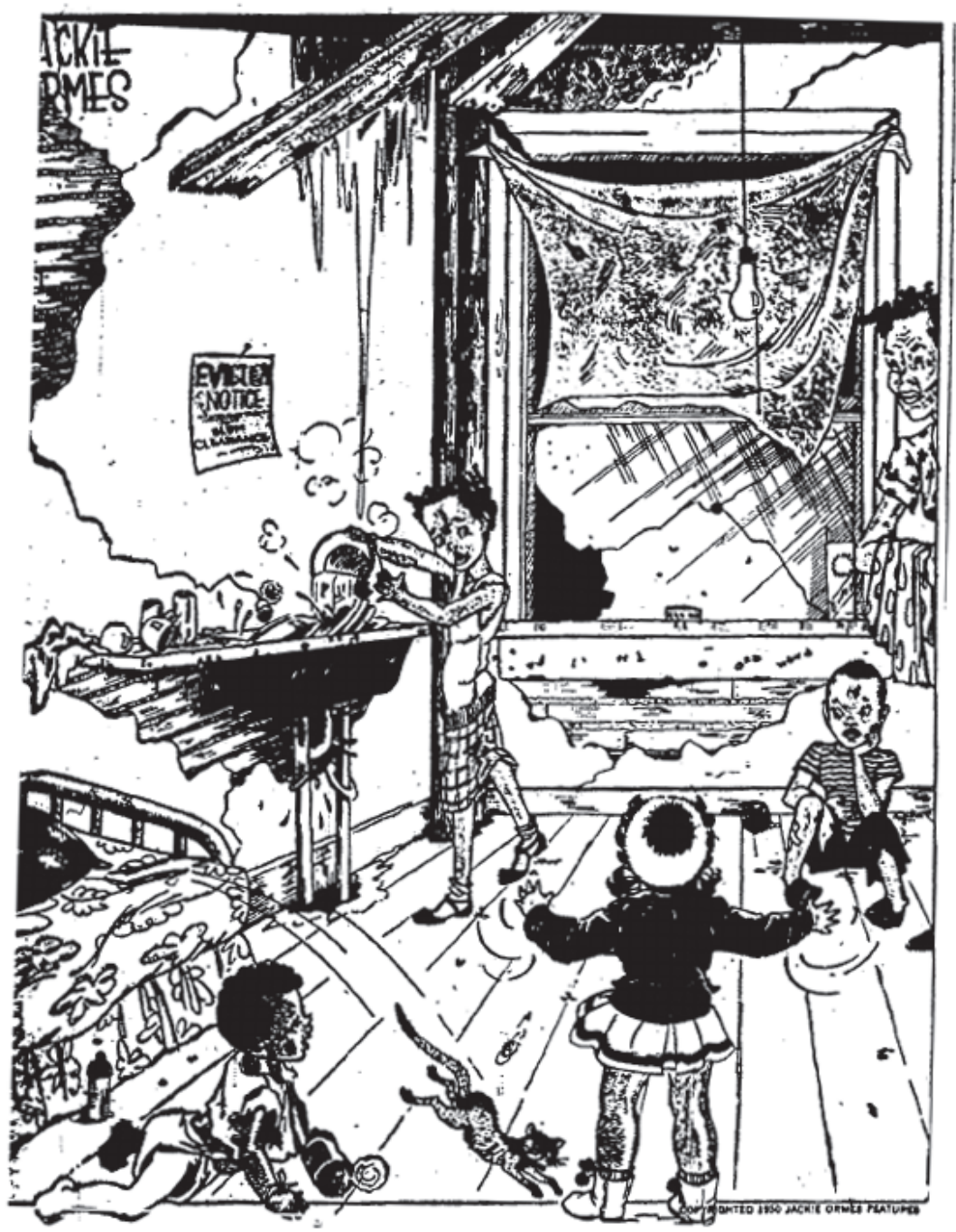

Figure 1. Jackie Ormes, Patty Jo ' $n$ ' Ginger, "Now you folks can REALLY stop worryin'... Uncle Sam's blowing our national wad on an H-bomb for your protection...course that don't spell HOUSING, but you gotta admit, it ain't HAY either!" Pittsburgh Courier, February 11, 1950. 
Despite Ormes's focus on presenting a very middle-class construction of African American life, the reader is regularly reminded that Patty Jo and Ginger are living within a larger Black community without universal access to wealth or necessary resources. This range of experiences, one may assume, imbued Patty Jo with her progressive opinions. She understood the complications of Black life, the impact of negligent political structures, and the fallout of race and gender inequality. This direct and stinging analysis was a radical statement for the Courier, even within the context of its regular coverage of racial and class inequality. It, again, positions Ormes as a kind of Black journalist who acted as a witness and sought to right societal inequity.

As African Americans pushed further for equality and America moved into a second Red Scare following the war, Ormes also centered commentary on the changing political climate of the late 1940s and early 1950s. Historian Mary L. Dudziak, in her work, Cold War Civil Rights: Race and the Image of American Democracy, outlines the ways in which the sudden Cold War opened the door to civil rights gains and, simultaneously, limited their scope. Under the spotlight of the world press, and in a global race to install political democracies, American aspirations were hobbled by disturbing civil rights coverage. The internal protest from civil rights activists became coupled with international pressure. This development took place in parallel with the national demonizing of internationalism, Communism, and the quelling of perceived radicalism, and led to a "narrowing of acceptable Civil Rights discourse" that left many vulnerable to state attack. ${ }^{26}$ Countless men and women, who were considered on the left by the FBI and other federal apparatuses such as the House Un-American Activities Committee (HUAC), had their careers and lives destroyed during this period.

HUAC investigated organizations and individuals that it identified as associated with Communism and became the primary governmental body that prosecuted those seen as espousing Communist ideals. In reality the committee targeted persons with a spectrum of political ideology and engagement. Opportunely HUAC labeled any related activism or espousing of interracialism as Communist, including Black organizations and their members that were deemed radical. Activist Esther Cooper Jackson, a founding editor of Freedomways and one of the organizers of the Committee in Defense of Black Leadership, noted that "there were several hundred African Americans who were either arrested or under contempt during the McCarthy era." ${ }^{27}$ The committee was formed in an effort to defend those that had become HUAC's victims. In her April 23, 1949 strip, Ormes criticized this committee. As Patty Jo and Ginger are out for a spring walk, Patty Jo points to a manhole that has a sign that reads "Men at Work." She insists to Ginger, "What'd I tell you . . . underground workers . . . 'jus wait till the un-American Committee hears about this!"28 At a time when many Black public figures were fearful of even a quiet critique of the national anti-Communism crusade, Ormes stepped directly into the fray.

Ormes continued her assault on fanatical anticommunism. In a July 24, 1948 strip, holding tight to her teddy bear, Patty Jo casually explains to her sister, "Naw...I don't see much of Benjie anymore. His dad gave him an important job 
of pulling wings off of flies...Left Ones!'29 Benjie was a friend of Patty Jo's who sometimes appears in the strip. His father is a character used to represent more conservative views. Although he never appears, his beliefs are mouthed through Benjie's character, and he acts as an important counterweight to the radicalized views of outspoken Patty Jo. She is making an innocent reference to the ongoing hearings and government persecution of those on the political left. The result for almost all of those brought before the committee was unrepairable disruption to their lives and, most often, the destruction of their careers.

Ormes likely built in this voice to talk back to the conservative element of the Courier readers and reporters. Despite the heavy toll it took on the Black community, there were those who supported not only antiradicalism and anticommunism, but the extremes of the committee. Well-known columnist George Schuyler was an avid supporter of Senator Joseph McCarthy. ${ }^{30}$ He worked at the Courier at the same time as Ormes did. His column, Views and Reviews, ran titles such as, "Victims of Race Prejudice are Not Helpless!" and "Where else in the World Will a Negro Woman Drive a Cadillac?"31 His column included critiques of the Black community, whom he saw as greatly benefitting from American citizenship, as well as a push for bootstrap capitalism. He also toed the government's antiradical line, often launching his own "red" accusations during the blacklisting period. He was to the extreme right even within Black conservatism. In 1954, as McCarthy was finally being silenced by the Senate, Schuyler published an incendiary article entitled "The Lynching of McCarthy" which portrayed McCarthy as a victim of a "nefarious conspiracy" by those trying to bring him down. ${ }^{32}$ These views did not seem to be in line with most of the Courier's readers. He often caught their ire. The "letters to the editors" section was regularly full of responses to his columns. One respondent said that he "always considered the Courier in the vanguard of the fight for civil rights and progress," and for this reason, he said, a recent rise in price to twenty cents had not discouraged him from buying it. However, the idea that he was supporting "a person like George Schuyler" was "too much for [him] to bear." He added, "and I know there must be thousands who feel the same way." 33 Benjie, who unwittingly spoke the words of his father, became a stand-in for journalists such as Schuyler, and more specifically, for the Black conservatism that was the antithesis of Ormes's comic's messaging.

Through her comic art Ormes joined the chorus of Black journalists who condemned rabid anticommunism. Of course, it was not enough to save those accused. Many Black artists, actors, musicians, and newspaper personnel who were politically active in the 1930s and 1940s would have their careers dismantled in the early 1950s. Ormes's colleague and fellow cartoonist Oliver Harrington was an early victim of the government's anticommunist witch hunt. Among other activities, he was pursued due to his work with W.E.B. Du Bois and the NAACP as well as his role in Communist Benjamin Davis's campaign for New York City Council. After years of harassment, he left America for France in $1951 .{ }^{34} \mathrm{He}$ was exiled, never to live in his country of birth again. Artists were particularly vulnerable as their living depended on public acceptance and wide popularity. 
Virtuoso pianist Hazel Scott, whose The Hazel Scott Show was the first to be hosted by an African American and primarily featured musical entertainment by its host, went from being one of the highest paid Black entertainers in the nation to unbookable after her appearance before HUAC in $1950 .{ }^{35}$ Actor, singer, and athlete Paul Robeson would not be called before the committee until 1956, but his career had already been greatly diminished. The State Department revoked his passport in 1950 due to his prolific activism and Communist associations, leaving him unable to perform in the States or abroad. The most popular Black performer of his time, Robeson became a prominent symbol of the price of Communist affiliation and, more particularly, interracial radical activism. These are but a few of the many visible Black celebrities, artists, and activists who were felled by HUAC. The haphazard manner of the accusations instilled the fear that it was intended to. Ormes herself was fortunate not to be blacklisted; however, the FBI developed a keen interest in her activities.

In March of 1951, notably the same year that Harrington was forced to flee, one strip finds Patty Jo returning from church reporting to her sister,

"So, like I said, the Rev. Mr. Holy was leading the congregation in prayer and got us into a wonderful chorus of PEACE MONGERING when Uncle Bootsie yelled 'Lawd an' MR. TRUMAN, TOO!' . . . then a mother jumped straight up an' shouted AMEN . . . that's when the preacher stopped cold an' said: 'This is Easter, Brother Bootsie, let's keep it CLEAN. We don't want no FBI in here!"" 36 (Figure 2)

Patty Jo is astonished that gathering together for peace may bring down the weight of the FBI at the mere mention of President Truman's name. She also may be giving a sly wink to the readers concerning the treatment of Oliver Harrington. She includes a brazen reference to Harrington's "Brother Bootsie," indicating her solidarity with her fellow cartoonist.

The campaign to end progressive and radical organizing was widely effective. The more liberal and narrower scope of the Civil Rights Movement arose in place of the Popular and Cultural Front-based activism of the 1930s and 1940s. Ormes was undeterred, and published numerous strips containing blatant critiques of the treatment of her community, and often close friends, by government forces. The importance of the "peace mongering" strip stretches beyond Ormes's spotlighting of repression. Patty Jo and Ginger reminded readers that they were a part of a larger beloved Black community. The single-frame Patty Jo shows the characters most often in their middle-class home, but when they leave their environs, they exist in a mixed-income segregated Black space, which would have been the experience of many African Americans. The days of fully middle- or upper-middle-class standalone Black neighborhoods were, for the most part, located in the future. Harrington and Ormes were mirroring not only their own thoughts but those of their community. 


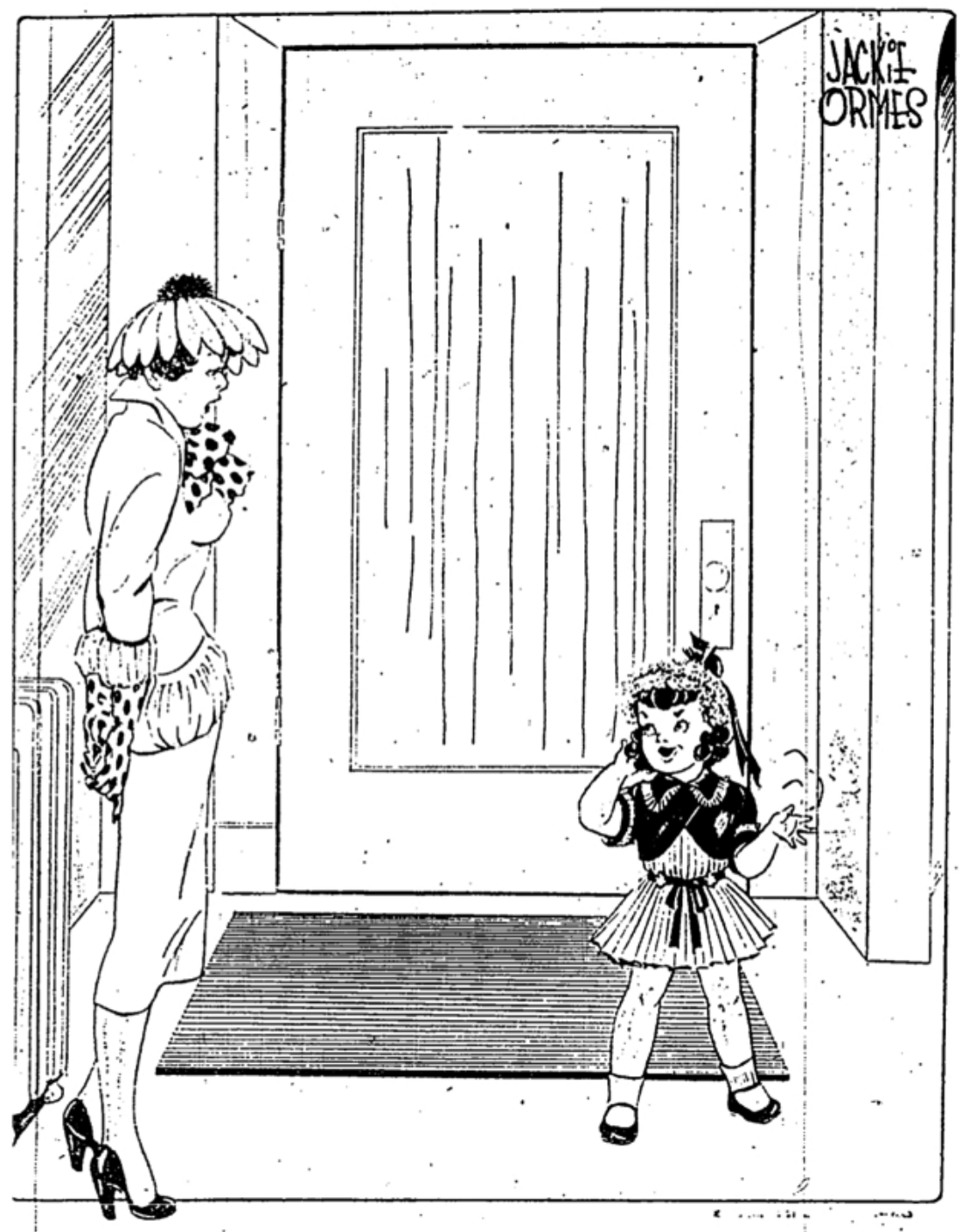

Figure 2. Jackie Ormes, Patty Jo ' $n$ ' Ginger, "So, like I said, the Rev. Mr. Holy was leading the congregation in prayer and got us into a wonderful chorus of PEACE MONGERING when Uncle Bootsie yelled 'Lawd an' MR. TRUMAN, TOO!'...then a mother jumped straight up an' shouted AMEN...that's when the preacher stopped cold an' said: 'This is Easter, Brother Bootsie, let's keep it CLEAN. We don't want no FBI in here!'” Pittsburgh Courier, March 24, 1951. 
Still espousing beliefs fueled by the Popular Front, Ormes concurrently took up the causes of the burgeoning Civil Rights Movement in her comics. Ginger remains an ever silent and reflective character in Patty Jo ' $n$ ' Ginger; contrarily, Patty Jo is well informed and ever more tenacious. In the October 8, 1955 strip Patty Jo walks into the living room from the kitchen and explains to her sister, "I don't want to seem touchy on the subject...but that new little white tea kettle just whistled at me!"37 (Figure 3) This dialogue is a reaction to the 1955 murder of Emmett Till, a fourteen-year-old who was taken from his home, beaten to death, and weighted down in a river with a cotton gin fan. He was accused of whistling at a white woman in a shop while visiting his great uncle in Money,

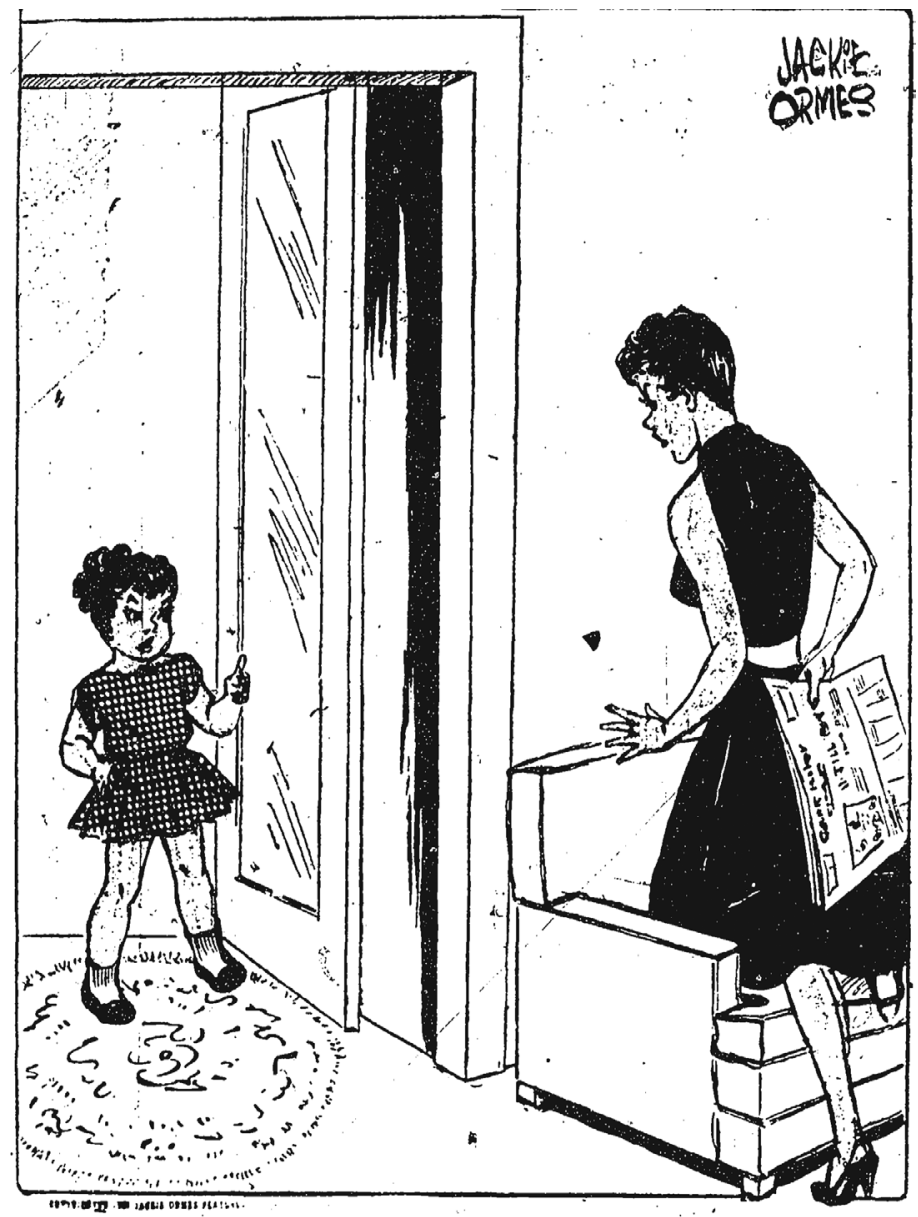

Figure 3. Jackie Ormes, Patty Jo ' $n$ ' Ginger, "I don't want to seem touchy on the subject...but that new little white tea kettle just whistled at me!" Pittsburgh Courier, October 8, 1955. 
Mississippi. African Americans reacted with horror and outrage. His death must have been further salient for the cartoonist because Till and his mother lived in Chicago, where his broken body was ultimately viewed, and his funeral held.

Till's murder became a touchstone for the Black community nationwide and marked a turning point for the Civil Rights Movement due to the widespread coverage by the Black press. Jet, the premier Black magazine, reported on Till's funeral and included explicit pictures of his mutilated body. Surely Ormes felt the weighty grief experienced in her Chicago community following his death. Yet her strip goes further and reveals the pervasive feelings of anger and dismay that African Americans were experiencing about the all too familiar racial violence. Patty Jo's response is not one of sorrow but one of ridicule of the vile absurdity of killing a fourteen-year-old boy for whistling at a grown white woman. Ormes was able to voice this by exploiting Patty Jo's youth and seeming innocence. Using the metaphor of a "little white tea kettle" Ormes condemns unrelenting and senseless racial violence. She also acknowledges the double standard embedded in American racial and sexual violence. Patty's pronouncement implicitly raises the specter of the historic racialized sexual violence that befell Black women that went unpunished. ${ }^{38}$ In using the comic section of the Black newspaper as a political space, Ormes delivers a scathing critique of taboo subjects such as segregation, miscegenation, and rape without inviting the kind of backlash that similar sentiments prompted in other media formats such as articles, films, or plays.

In a strip published on March 31, 1956 Patty says enthusiastically to Ginger, "You guessed it! Bundle for the South...Montgomery, Ala., that is." 39 The little girl is carrying a pair of roller skates for shipping. She is referencing the Montgomery Bus Boycott, which had started four months earlier when activist and seamstress Rosa Parks refused to give up her seat to a white patron on a segregated bus. Her subsequent arrest led to a 381-day boycott of the public buses. The boycott began only months after the Till murder. In fact, Parks has stated that she was thinking of Till during the pivotal confrontation. ${ }^{40}$ Ormes placed Patty Jo into the national conversation about civil rights many times throughout the strip's run. By doing so, Ormes echoed the gallant work of the progressive Black press during the Civil Rights Movement. Legendary reporter Ethel Payne was amongst the first "out of town" journalists to reach Montgomery. Her home paper, The Chicago Defender, had not sent many reporters to the frontlines in the South. Her coverage of Montgomery helped add urgency and made the boycott headlines in the mainstream media. The New York Times and Washington Post had not bothered to send reporters. But Payne insisted to her editors that there was a quickly developing "civil rights beat" to cover. ${ }^{41}$ Ormes's strip resonated with the same urgency. The coverage was driven by the Black press. They continually called attention to the inequality that pervaded Black life and the actions taken by civil rights activists, and they were directly instrumental in the social and legislative gains. 


\section{Jackie Ormes and the Costs of On- and Off-the-Page Activism}

As the Civil Rights Movement gained momentum, Ormes's off-the-page activism had consequences. The year of the release of the aforementioned One Tenth of a Nation film, 1953, also marked the time at which the Federal Bureau of Investigation took a keener interest in her activities. According to her FBI file, agents had been monitoring her activity since 1948 due to her attendance at a talk that included several Communist Party (CP) members. Apparently, her political activity raised suspicion. The Bureau, often in tandem with HUAC, also investigated anyone that it saw as being involved in radical Black activism after World War II. Ormes was under surveillance for at least the next five years. The Bureau's main concern was Ormes's possible connection to the Communist Party and her friendships with influential members such as Geraldyne and Claude Lightfoot, Paul Robeson, and W.E.B. and Shirley Graham Du Bois. ${ }^{42}$

The inevitable investigation of Ormes by the FBI also stemmed from her regular participation in activist organizations. For example, she was a member of the radical South Side Community Arts Center and the NAACP. This was in addition to her support of community activities sponsored by the Freedom Associates, Progressive Party, and American Peace Crusade, as well the Civil Rights Congress, among others. All were on the government-sanctioned list of subversive organizations. ${ }^{43}$ A number of scholars have published studies on the work of Black women who were in or associated with the Communist Party and larger freedom movements. ${ }^{44}$ It is unclear if Ormes belonged formally to this sisterhood, but her proximity to radicalism, radical organizations, and activists is unquestionable. This raised her profile enough that the FBI became suspicious of her activities.

Various agents conducted several interviews with Ormes between 1953 and 1958. ${ }^{45}$ If FBI memos are to be believed, the cartoonist used a number of tactics to confuse, charm, or frustrate her interrogators. According to her FBI file she put off agents as long as she could and was finally cornered at her residence on May 18, 1953. In her first interview, an agent included questions that were "designed to give the subject an opportunity to express her views," asking about "Korea, Russia, the Smith Act, the Communist Party and the Negro question." The questions appear to be a litmus test for patriotism, as all of these were controversial topics that they related to Communist infiltration. On each subject Ormes's response was polite but defiant. She explained that America should not have been involved in the Korean conflict and that she saw Russia as advancing socially and culturally but posing no threat to the U.S. ${ }^{46}$

In contrast to many individuals interviewed who unequivocally distanced themselves from the CP and its philosophies, Ormes seems unfazed and purposely enigmatic. In their reports agents alternately described her as "well-read and intelligent" and "flighty." Perhaps they had a hard time seeing this petite attractive comic artist as a viable threat. No doubt she used these racist and sex- 
ist assumptions to her advantage. She freely expressed her political views and her evaluation of the CP. In several interviews, while denying membership in the $\mathrm{CP}$, she discussed its merits. On one occasion, she "engaged the agents in a rather lengthy discussion of the Communist movement... she had stated she felt the Communist movement to be an innocuous one which...constituted no apparent threat to the continued existence of this country's form of government." She added that she believed "Communists were being investigated and persecuted because of their activities in breaking down racial barriers, exacting more benefits from capital interests for the working class," and she told another agent that she had worked "on the fringe" with many of the organizations in Chicago that were considered subversive by the FBI, and that "if her alignment with any such organization was considered tantamount to CPUSA membership by the FBI or CPUSA, she had no defense." ${ }^{47}$ Ormes's responses point to the danger inherent in past or present association with the CPUSA or allied organizations. Many people were forced to deny their full involvement. It should be noted that nearly all kinds of organizing, resistance, and activism by African Americans in the WWII and post-WWII era could be and was considered radical by the United States government.

Alternatively, her response also reflects another reality. Many African Americans who engaged in social and political work viewed the CPUSA as simply another venue of activism, but also held reservations about the Party's motives within the Black community. Black-led organizations were always deeply involved in the fight for freedom and equality; the CPUSA very often joined movements or actions begun by Black leaders, local and national organizations, and everyday Black folks. Ormes's location in Black metropolitan Chicago would have influenced her art as well as her understanding of activism. The city was the site of a busy Black activist front, including organizations that were Communist-affiliated. Black Studies scholar Bill Mullen argues that the impact of Black organizing was so great in Chicago that it extended the Popular and Cultural Fronts long after the CPUSA began to collapse. ${ }^{48}$ The full history of the brave activism of African American men and women in Chicago is still being fully written, as their connections to radical organizations were cloaked in secrecy or erased over time. In any case, Ormes's comments would have drawn more attention to her, rather than less. She may have escaped the severe repercussions that were visited upon many other Black celebrities, artists, and activists in the era of the Blacklist because the FBI decided she was benign. She also benefitted from working and living in segregated spaces. The Courier was a Black newspaper with a Black staff, funded by a Black readership. She would not have lost great numbers of readers based on governmental accusations. Her husband, Earl Ormes, the main economic earner in her home, managed the Sutherland Hotel, a posh establishment catering to African Americans. ${ }^{49}$ This, of course, did not place her out of the reach of the government and its forces, but it did provide some cover. 
Nancy Goldstein, Ormes's biographer, rightly notes that if the FBI had wanted to truly discern her political views, all they had to do was to thumb through the Courier and read her comics. ${ }^{50}$ Ormes's outspokenness on progressive and radical issues was expressed clearly in the comic pages of the Pittsburgh Courier. In spite of governmental harassment, or maybe because of it, Ormes continued to use her comics as a political platform from which to deliver powerful societal critiques. The FBI conducted formal interviews with Ormes on May 5 and July 29 of 1953 as well as February 13, 1955 and February 13, 1956. If Courier readers had known this they would have seen little change in the political engagement in the panes of Patty Jo. In fact, beyond progressive Black journalism, an astute reader may have seen a kind of real-time talking back to the FBI and government suppression — a significant decision given that many people dissociated themselves from public political involvement of any kind for fear of incrimination. On May 4, 1953 Patty Jo ' $n$ ' Ginger featured a portrait of Patty in the doctor's office. She stands behind an X-Ray machine and her skeleton is visible through its screen. She says to the nearby M.D., "So locate the MARBLE, Doctor McCarthy an' lemme out of here ... Anything else you might see is strictly personal, and after all, I got my RIGHTS!'51 (Figure 4) Incredibly, this strip was published the very day before the FBI's first interview of Ormes. It is unlikely that they had reviewed her work, as the outcome of the interview may have been very different. In this strip, Patty Jo articulates what is on the minds of many Americans, which is remarkable considering the danger this could have placed Ormes in.

The cartoonist continued her critique of McCarthy in June of 1954. She draws Patty Jo and Ginger taking a walk. Patty Jo reflects to her sister, "Now take the sun f'rinstance . . . wouldn't you say it's a very welcome ambassador from the Far East? . . . Or will Mr. McCarthy have us viewing IT with alarm before summer's over?"52 (Figure 5) Patty is again taking stock of the overzealous and dangerous nature of McCarthy's hunt for those labeled Communists or radicals. Ormes also published the October 1955 strip referencing the Emmett Till trial during the time of her interrogation by the FBI. This unrelenting resistance was only a part of a larger freedom struggle for Ormes. The historic Brown v. Board of Education decision, which declared school segregation to be unconstitutional, was handed down in May of 1954, and a resolution for McCarthy's censure was submitted in July of the same year due to the overreaching of his committee and tactics. Unfortunately, the blacklist era did not end with his removal and much of the damage was already inflicted. However, the Popular and Cultural Front activism and protest of anticommunist forces, like that of Ormes and her character, had paved the way for the rising Civil Rights Movement.

Ormes's defiance endured. As the Patty Jo ' $n$ ' Ginger strip continued its run, Ormes created another dynamic, woman-centered strip called Torchy in Heartbeats. It ran from 1950 to 1954 in the Sunday edition in vivid color. The Torchy character is reimagined from her 1930s iteration. The modern Torchy was based on the life of a single African American woman who travels the world, becomes 


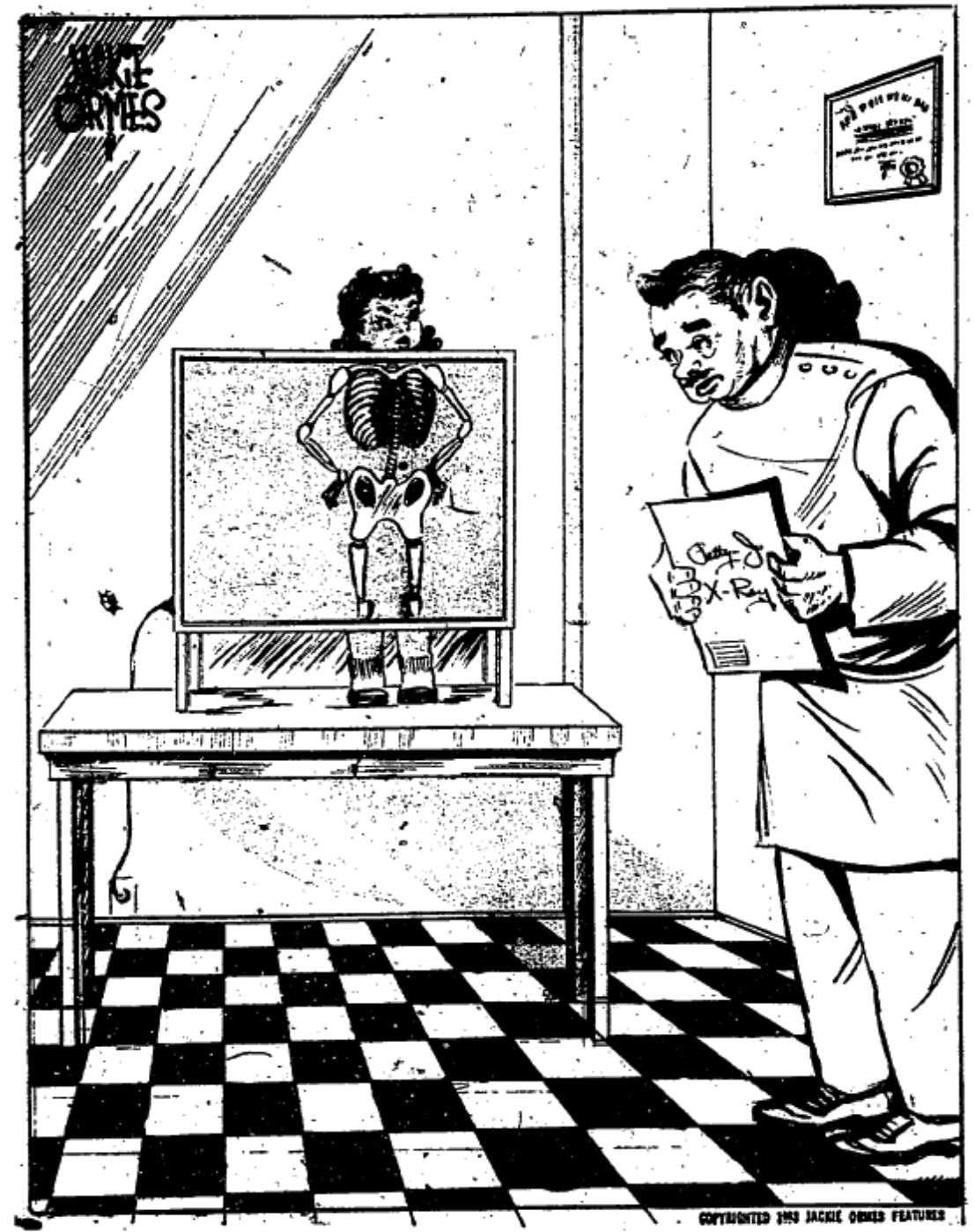

Figure 4. Jackie Ormes, Patty Jo ' $n$ ' Ginger, "So locate the MARBLE, Doctor McCarthy an' lemme out of here...Anything else you might see is strictly personal, and after all, I got my RIGHTS!" Pittsburgh Courier, May 4, 1953.

involved in a slew of adventures, and practices several professions along the way. She is a fearless independent woman who uses her many talents to combat injustice. What the FBI would have classified as subversion can be found herein as well. Torchy combats bigotry, racial oppression, and environmental racism 


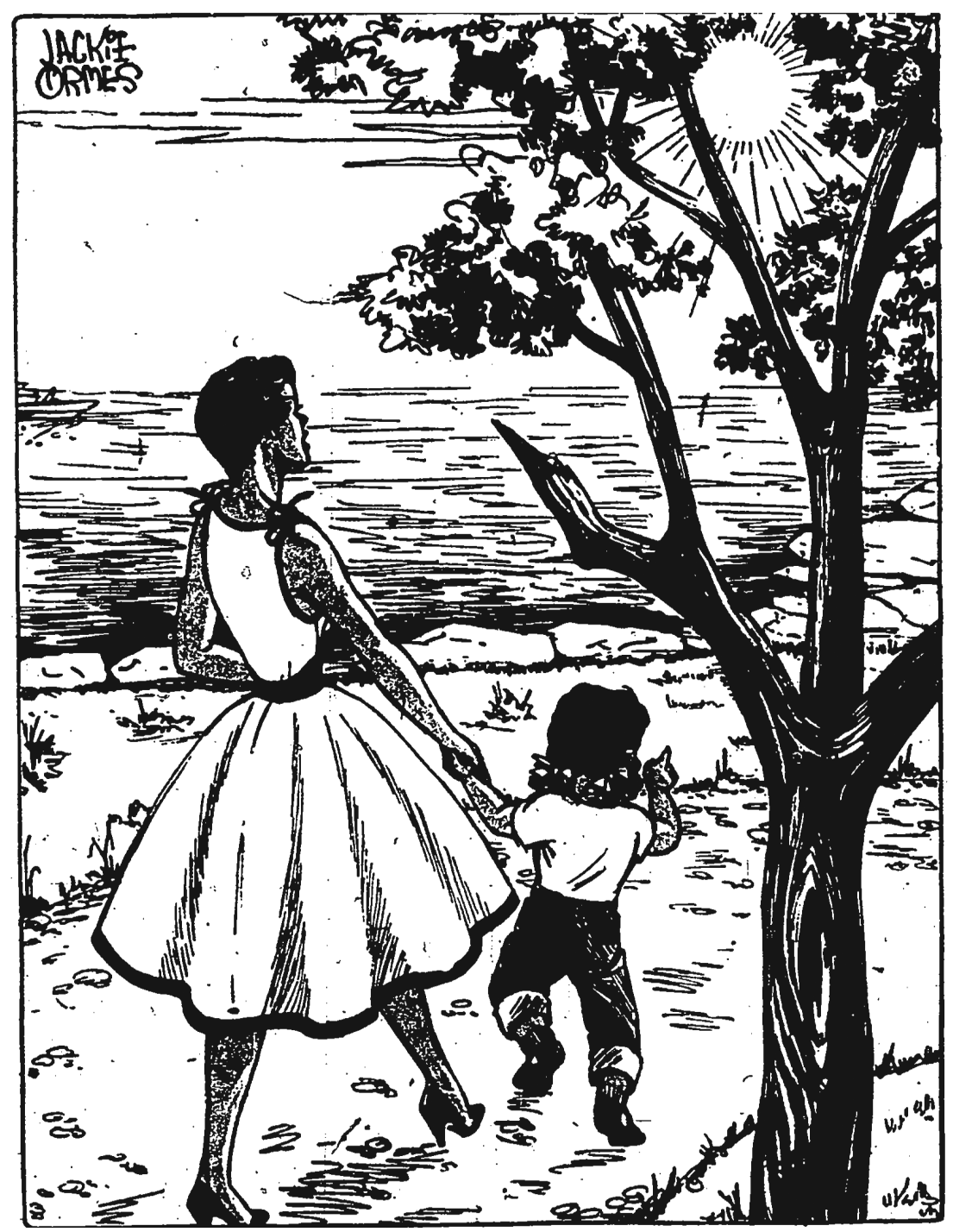

Figure 5. Jackie Ormes, Patty Jo ' $n$ ' Ginger, "Now take the sun f'rinstance... wouldn't you say it's a very welcome ambassador from the Far East? ... Or will Mr. McCarthy have us viewing IT with alarm before summer's over?" Pittsburgh Courier, June 12, 1954.

in the Deep South. She tackles sexism, sexual harassment, and rape at home and abroad. Situated in the mid-1950s, Ormes's Torchy introduced discussions that would not enter the national consciousness for decades. In many ways, due to her exploits, Torchy can easily be read as the first African American female 
superhero of sorts. Patty Jo kept up her antics in her single pane as Ormes expanded her sites of resistance.

Because of her constant drawing, Ormes suffered from severe rheumatoid arthritis. She stopped her strips in 1956 and lost much of the function in her hands by her death in $1985 .{ }^{53}$ They held the trauma of a long career. This is ironic, since her hands were her principal weapons against all forms of oppression and repression that plagued Black America and Black women in her lifetime. Her comics are a testament to the unique constructions of activism African American women engaged in and the multipronged resistance that they waged. Ormes's political activist labor off the page, and, more notably, her activism in radical messaging and image-making within the panes of her comic strips, reveals much about the nature of this resistance and its many unseen forms. Ormes's contributions are clear. She used her pioneering comics as a form of progressive Black journalism, using a Black female voice, and citing Black women's concerns. Her chosen art form and its location, in the funny pages of the Black press, were made both subversive and radical in her hands. Although long hidden from Civil Rights Movement, art, and journalistic histories, her important work deserves inclusion, as she is linked to a mid-century community of Black women activists, artists, and journalists who, like her, were the distinguished vanguard of being "anti-everything."

\section{Notes}

1. Raymond Fielding, The American Newsreel, 1911-1967 (Norman: University of Oklahoma Press, 1972), 187-88.The All-American News, founded in 1942, was the sole newsreel that "featured news and feature material calculated to be of particular interest to black citizens." This series ran in 365 of the nation's 451 Black theaters. The Office of War Information believed that $85 \%$ of Blacks in the five largest cities received much of their news from this series. This evaluation fails to take into account Black newspapers where Black people more than likely received most of their news.

2. Langston Hughes, "Colored and Colorful," Chicago Defender, June 26, 1948, 14.

3. Mia Bay, Farah J. Griffin, Martha S. Jones, and Barbara D. Savage, eds., Toward an Intellectual History of Black Women (Chapel Hill: University of North Carolina Press, 2015); Brittney C. Cooper, Beyond Respectability: The Intellectual Thought of Race Women (Urbana: University of Illinois Press, 2017); Ayesha K. Hardison, Writing Through Jane Crow: Race and Gender Politics in African American Literature (Charlottesville: University of Virginia Press, 2014).

4. David Jackson, "The Amazing Adventures of Jackie Ormes," Reader: Chicago's Free Weekly 14, no. 46 (August 16, 1985), 24.

5. Nancy Goldstein, Jackie Ormes: The First African American Woman Cartoonist (Ann Arbor: University of Michigan Press, 2008).

6. Edward Brunner, "'Shuh! Ain't Nothin' to It': The Dynamics of Success in Jackie Ormes's 'Torchy Brown,"' MELUS 32, no. 3 (2007): 23-49.

7. Deborah Elizabeth Whaley, Black Women in Sequence: Re-inking Comics, Graphic Novels, and Anime (Seattle: University of Washington Press, 2016), 46.

8. Fred Carroll, Race News: Black Journalists and the Fight for Racial Justice in the Twentieth Century (Urbana: University of Illinois Press, 2017), 5.

9. Gene Roberts and Hank Klibanoff, The Race Beat: The Press, The Civil Rights Struggle, and the Awakening of a Nation (New York: Alfred A. Knopf, 2006), 16.

10. Roland Wolseley, The Black Press, USA, 2nd ed., (Ames: Iowa State University Press,1990), 6.

11. Wolseley, The Black Press, USA, 3-4.

12. Goldstein, Jackie Ormes, 63.

13. Jackson, "The Amazing Adventures of Jackie Ormes," 24.

14. M. Thomas Inge, ed., Dark Laughter: The Satiric Art of Oliver W. Harrington (Jackson: University Press of Mississippi, 1993), xviii-xxviii. 
15. Writer Alice Childress created a Black women domestic character for the serial "Conversations from Life" that appeared in the Black Marxist newspaper, Freedom. She too was outspoken and astute. The series was published as a book entitled Like One of the Family in 1956.

16. Jackie Ormes, "Candy," Chicago Defender, July 21, 1945.

17. Jackie Ormes, "Candy," Chicago Defender, April 7, 1945.

18. Ann Petry, The Street (Boston: Houghton Mifflin Co., 1946)

19. Claudia Jones, "An End to the Neglect of the Problems of the Negro Woman!" (New York: National Women's Commission, C.P.U.S.A., 1949), 4.

20. Maureen Honey details the many roles and voices of African American women during World War II as read in African American newspapers. Maureen Honey, ed., Bitter Fruit: African American Women in World War II (Columbia: University of Missouri Press, 1999).

21. Jacqueline Jones, Labor of Love, Labor of Sorrow: Black Women, Work, and the Family, From Slavery to the Present (New York: Basic Books, 2010), 201.

22. Maurice Horn, Women in the Comics (New York: Chelsea House Publishers, 1977), 92.

23. Charlene Regester includes a discussion of this phenomenon in her book African American Actresses: The Struggle for Visibility, 1900-1960 (Bloomington: Indiana University Press, 2010), 6-7.

24. Trina Robbins and Kristy Valenti, Pretty in Ink: North American Women Cartoonists, 1896-2013 (Seattle: Fantagraphics Books, 2013), 105.

25. Ormes, "Patty Jo 'n' Ginger,” Pittsburgh Courier, February 11, 1950.

26. Mary L. Dudziak, Cold War Civil Rights: Race and the Image of American Democracy (Princeton, NJ: Princeton University Press, 2000), 13.

27. Mary Helen Washington, "Alice Childress, Lorraine Hansberry, and Claudia Jones: Black Women Write the Popular Front," in Left of the Color Line: Race, Radicalism, and TwentiethCentury Literature of the United States, eds. Bill V. Mullen and James Smethurst (Chapel Hill: University of North Carolina Press, 2003), 185.

28. Ormes, “Patty Jo ‘n’ Ginger,” Pittsburgh Courier, April 23, 1949.

29. Ormes, "Patty Jo 'n' Ginger,” Pittsburgh Courier, July 24, 1948.

30. It should be noted that George Schuyler's politics changed over time and were complex. He was a literary figure during the Harlem Renaissance who was, at that time, interested in socialism and wrote a celebrated book entitled Black No More that critiqued race, racism, and organized religion's impact on Black America. By the 1950s his politics had shifted to the far right. His writing in the Pittsburgh Courier reflected this turn. George S. Schuyler, Black No More: Being an Account of the Strange and Wonderful Workings of Science in the Land of the Free, A.D. 1933-1940 (New York: The Macaulay Company, 1931).

31. George Schuyler, "Views and Reviews: Where else in the World Will a Negro Woman Drive a Cadillac?", Pittsburgh Courier, September 2, 1950, 21; George Schuyler, "Views and Reviews: Victims of Race Prejudice are Not Helpless!", Pittsburgh Courier, September 23, 1950, 17.

32. George Schuyler, "The Lynching of McCarthy," Pittsburgh Courier, November 6, 1954.

33. Charles Jackson, "Says George Schuyler Hinders Race Progress," Pittsburgh Courier, December 15,1951 .

34. Inge, Dark Laughter xxxiv-xxxv; Herb Boyd, “Ollie Harrington: In Memoriam,” Black Scholar 26, no. 1 (Winter/Spring 1996): 74. Harrington would continue to send correspondence, art and comics from abroad. He was a steady presence in the Black press into the 1980s despite his exile.

35. Committee on Un-American Activities, United States House of Representatives, Hazel Scott Powell Hearings, 81st Cong., 2d sess.,

1950.

36. Ormes, "Patty Jo 'n' Ginger," Pittsburgh Courier, March 24, 1951

37. Ormes, "Patty Jo 'n' Ginger," Pittsburgh Courier, October 8, 1955.

38. Danielle L. McGuire discusses this at length in her text At the Dark End of the Street: Black Women, Rape, and Resistance: A New History of the Civil Rights Movement from Rosa Parks to the Rise of Black Power (New York: Vintage, 2011).

39. Ormes, "Patty Jo 'n' Ginger," Pittsburgh Courier, March 31, 1956.

40. Jeanne Theoharis, The Rebellious Life of Mrs. Rosa Parks (Boston: Beacon Press, 2013),

41. James McGrath Morris, Eye on the Struggle: Ethel Payne, the First Lady of the Black Press (New York: Harper Collins, 2015), 176-77, 180.

42. Federal Bureau of Investigation, Memorandum, SAC [Special Agent in Charge], Chicago Field to Director, FBI (Chicago: Chicago Field Office Jackie Ormes Bureau File, February 27, 1956).

43. Federal Bureau of Investigation, Memorandum, $S A C$.

44. Feminist historian Dayo Gore's Radicalism at the Crossroads: African American Women Activists in the Cold War unearths the forgotten labor of radical Black women activists. Her text emphasizes the groundwork laid by key women and the activist networks they built. It also testifies to the central roles they played in the CPUSA and radical Black left freedom movements. Included 


\section{H. Zahra Caldwell}

in Gore's examination is editor Marvel Cooke who personified radical journalism and worked for, among other outlets, The People's Voice. Her tenure at the paper was concurrent with that of Oliver Harrington. Ormes was in good artistic and journalistic company. Historian Erik McDuffie also refutes the idea that these women were anomalous. Rather, he situates them as a "part of a community of Black women radicals" whose activism spanned a good part of the twentieth century. Erik S. McDuffie, Sojourning for Freedom: Black Women, American Communism, and the Making of Black Left Feminism (Durham, NC: Duke University Press, 2011), 7; Dayo F. Gore, Radicalism at the Crossroads: African American Women Activists in the Cold War (New York: New York University Press, 2011), 22-23.

45. Both Nancy Goldstein and Deborah Elizabeth Whaley include important analyses of the FBI file. All indications are that Goldstein, her biographer, was the first to request it through the Freedom of Information Act. Future researchers owe her a debt for her thorough founding research.

46. Federal Bureau of Investigation, Memorandum, SAC [Special Agent in Charge], Chicago

Field to Director, FBI (Chicago: Chicago Field Office Jackie Ormes Bureau File, May 18, 1953).

47. Federal Bureau of Investigation, Memorandum, SAC.

48. Bill Mullen, Popular Fronts: Chicago and African American Cultural Politics, 1935-46 (Urbana: University of Illinois Press, 1999), 5.

49. Roi Ottley, "Owners Invest $\$ 300,000$ to Give South Side a First Class Hotel," Chicago Daily Tribune, April 15, 1956, 112.

50. Goldstein, Jackie Ormes, 31.

51. Ormes, "Patty Jo 'n' Ginger," Pittsburgh Courier, May 4, 1953.

52. Ormes, "Patty Jo 'n' Ginger," Pittsburgh Courier, June 12, 1954.

53. Jackson, "The Amazing Adventures of Jackie Ormes," 23. 